J. Japan. Soc. Hort. Sci. 56(3) : 321-327. 1987.

\title{
Roles of Temperature in the Occurrence of Hollow Root in Japanese Radish cv. 'Gensuke'
}

\author{
Yasutaka Kano \\ Ishikawa Agricultural College, Nonoichi, Ishikawa 921
}

\begin{abstract}
Summary
Lengthwise hollowness in the central part of roots occurrs frequently in summersown Japanese radishes, especially 'Gensuke'. To clarify the causes of this physiological disorder, root growth and the occurrence of hollowness in roots were investigated in 'Gensuke' sown from July to September at 15-day intervals, in 1984 and 1985. Furthermore, the effect on the roots of cooling the soil by piping cool water into the rows was investigated in summer-sown culture in 1984.

1. In both 1984 and 1985, maximum air and soil temperatures were highest during the period from July 31 to August 15 . In 1984, maximum soil temperature was reduced by about $6^{\circ} \mathrm{C}$ by the cooling treatment compared to that of the control, even in this period.

2. The greatest root weight 60 days after sowing was obtained in plants sown on July 17 in 1984 and July 1 in 1985. Hollow root began to increase from the 20-30 th day after sowing. In both 1984 and 1985, the occurrence 60 days after sowing was high in plants sown from the beginning to the middle of July, but low from the end of July to the middle of August.

3. The occurrence of hollow root was quite high in the control, but was low in the cooling treatment. Especially, the reduction of the occurrence by the cooling treatment was remarkable in plants sown during July.

From these results, I believe that high soil temperature is one of the important factors causing hollowness in roots of 'Gensuke'.
\end{abstract}

\section{Introduction}

'Gensuke' (Raphanus sativus L.), a cultivar of Japanese radishes, was selected from the natural hybrid between 'Gensuke sobuto' of Miyashige line and a local breed of Nerima line at Utsugi area in Ishikawa Prefecture (1) and has been cultivated in the sand dune regions of Ishikawa Prefecture because of its high quality since 1942 . The root of 'Gensuke' grows thick uniformly from proximal to distal part. The color of the upper portion of the root is greenish and root length is short(Fig. 1). This radish is marketed at a high price in the central wholesale market in Kanazawa city from the end of September

1 Received for publication August 27, 1986.

Part of this study was presented at the Annual Meetings of the Japanese Society for Horticultural Science, Tokyo, April and Kobe, October, 1985. to the middle of October (4). Therefore this radish is sown from August 10 on, and furthermore, sowing during July is much needed among the growers in these districts. In this case however, "hollow root" which has lengthwise hollowness in the central part of the root induced by a physiological disor$\operatorname{der}(\mathrm{s})$ has been frequently observed and gives much trouble to the growers in Kanazawa district. This injury is recognized in almost all Japanese radishes when the radishes are grown under high temperature(7), or low temperature(5) conditions and grown in the soil of low moisture(6), excess nitrogen(13), and high $\mathrm{pH}(8)$. On the other hand, any relationship between hollow root and boron content in plant and soil is not confirmed(6, 10).

This research was carried out in 'Gensuke? to investigate the influence of air and soil temperature during the growing period on 


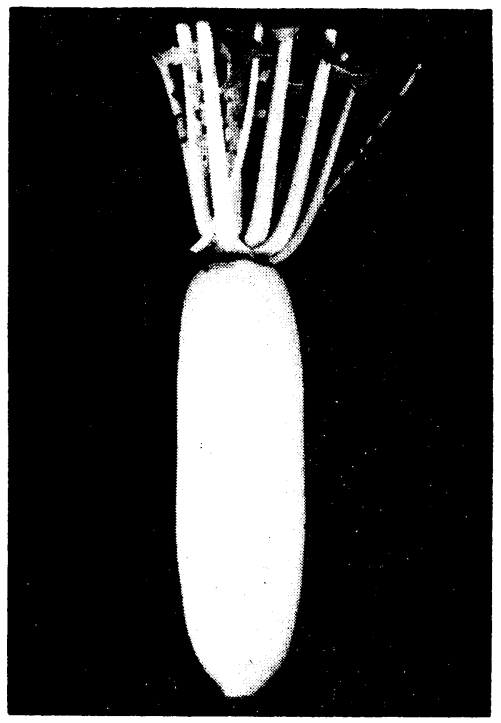

Fig. 1. External appearance of the root of 'Gensuke', a cultivar of Japanese radishes.

root growth and the occurrence of hollow root.

\section{Materials and Methods}

Experiments were carried out in the field of the experimental farm of Ishikawa Agricultural College. Two $\mathrm{kg} / \mathrm{m}^{2}$ of farmyard manure and $0.1 \mathrm{~kg} / \mathrm{m}^{2}$ of dolomite were applied at the middle of June and $10 \mathrm{~g} / \mathrm{m}^{2}$ of $\mathrm{N}, \mathrm{P}_{2} \mathrm{O}_{5}$ and $\mathrm{K}_{2} \mathrm{O}$ and $4 \mathrm{~g} / \mathrm{m}^{2}$ of FTE (Fritted Trace Elements) at the end of June. As top dressing, $4.6 \mathrm{~g} / \mathrm{m}^{2}$ of $\mathrm{N}$ was applied 14 days after sowing and $4.8 \mathrm{~g} / \mathrm{m}^{2}$ of $\mathrm{N}$ and $\mathrm{K}_{2} \mathrm{O} 25$ and 40 days after sowing. To investigate the effect of sowing date, 'Gensuke' seeds were sown on July 2 and 17 ; August 2 and 17 ; and September 1 in 1984 ; and on July 1, 16, and 31 ; and August 15 and 30 in 1985. Sixty plants were provided at all sowing dates. Ten plants were sampled 10,20, 30, 40, 50 and 60 days after sowing, with some exceptions, and root weight and hollowness were recorded. In this paper the term "root" refers to the swollen storage organ, which actually consists of the swollen hypocotyl and root. Upon observation of hollowness, roots were cut lengthwise at the central axis, and the maximum horizontal and longitudinal length of hollowness were measured. A root in which

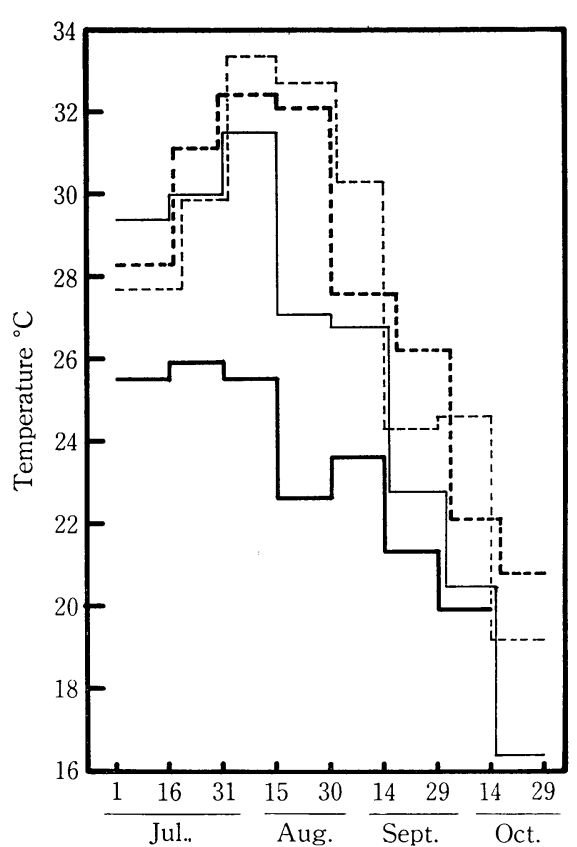

Fig. 2. Changes in maximum air temperature in 1984 $(--)$ and in $1985(--)$ and in maximum soil temperature of the control (-) and of the cooling treatment (-) in 1984.

the product of the horizontal and longitudinal length was above $200 \mathrm{~mm}^{2}$ was classed as a hollow root. To investigate effectiveness of lowering the soil temperature of the row, poly-vinyl hoses $(18 \mathrm{~mm}$ in diameter) were laid at $7 \mathrm{~cm}$ and $14 \mathrm{~cm}$ below the surface of the row, and cool water was run into the poly-vinyl hoses from $7: 00$ a. $\mathrm{m}$. to $7: 00$ p. m. throughout the growing period for 60 days. Seeds were sown on July 2, July 17, August 2 and August 17. Twenty plants were provided at all sowing dates. Ten plants were sampled 60 days after sowing, and root weight and the occurrence of hollow root were recorded.

Daily maximum air temperature was recorded throughout the growing period in both 1984 and 1985, and daily maximum soil temperature at a point $10 \mathrm{~cm}$ below the surface of the row in 1984. The mean of the daily maximum temperatures for 15 days was calculated. 


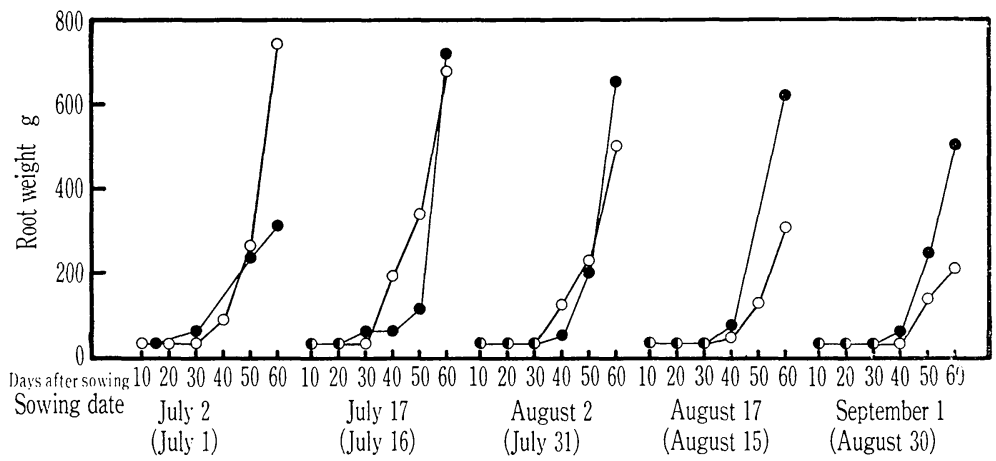

Fig. 3. Effect of sowing date on the growth of 'Gensuke' roots. Dates not parenthesized indicate sowing date in 1984, and parenthesized, 1985. Lines - $-\bigcirc$ and $\bigcirc-\bigcirc$ indicate the root weight of plants sown in 1984 and 1985, respectively.

\section{Results}

Changes in maximum air and soil temperature during the growing period

During the growing period, in both 1984 and 1985, maximum air temperature was highest in the period July 31 to August 15, and lowest from October 14 to 29(Fig. 2). In 1984, the highest maximum soil temperature of the control for sowings on July 2, July 17 and August 2 was $31.5^{\circ} \mathrm{C}$ in all cases, but $27.1^{\circ} \mathrm{C}$ for the sowing on August 17 (Fig. 2). On the other hand, maximum soil temperature with the cooling treatment remained below $25.9^{\circ} \mathrm{C}$ throughout the growing period.

Effect of sowing date on root growth and the occurrence of hollow root

Root weight increased rapidly from the 2030 th day after sowing in both 1984 and 1985 (Fig. 3). In 1984, the weight 30 days after sowing was great in plants sown during July, while the weight was small in plants sown from August 2 and on. At the end of the usual growing period, 60 days after sowing, however, the weight was smallest in plants sown on July 2, and greatest $(717 \mathrm{~g}$ ) in those sown on July 17 . The weight in plants sown from August 2 on became smaller with later sowing dates. In 1985, 60 days after sowing, a weight of $740 \mathrm{~g}$ in plants sown on July 1 was the greatest, and then the weight became smaller with later sowing dates.

Two types of hollowness were observed in

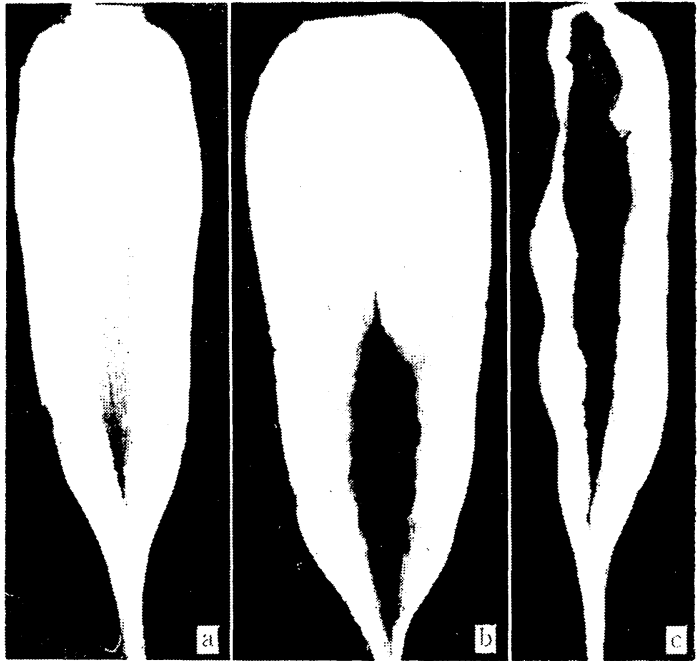

Fig. 4. Several types of hollowness in the root of 'Gensuke'.

a : an unstained hollowness. b : a hollowness stained blackish-brown. c : a very severe hollowness stained blackish-brown.

both 1984 and 1985(Fig. 4). One was an unstained hollowness(Fig. 4-a), and the other was a hollowness stained blackish-brown (Fig. 4-b, c). The degree of hollowness ranged from light to severe. In the most severe hollow root, the remaining root tissues were merely $1-2 \mathrm{~cm}$ thick (Fig. 4-c). No hollow root could be observed 10 days after sowing in both 1984 and 1985, but hollow root began to be observed 20-30 days after sowing(Fig. 5). In 1984, the occurrence of hollow root was $30 \%$ in plants sown on July $2,40 \%$ in plants sown on July 17,50 days after sowing, and $70 \%$ and $90 \%$, respective- 


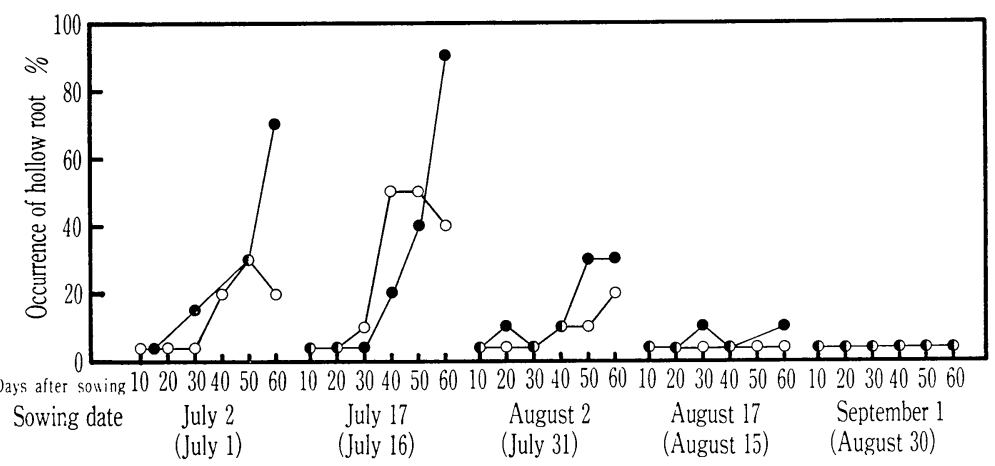

Fig. 5. Effect of sowing date on the occurrence of hollow root in 'Gensuke'. Dates not parenthesized indicate sowing date in 1984, and parenthesized, 1985. Lines and $\mathrm{C}-\bigcirc$ indicate the occurrence of hollow root in 1984 and 1985, respectively.

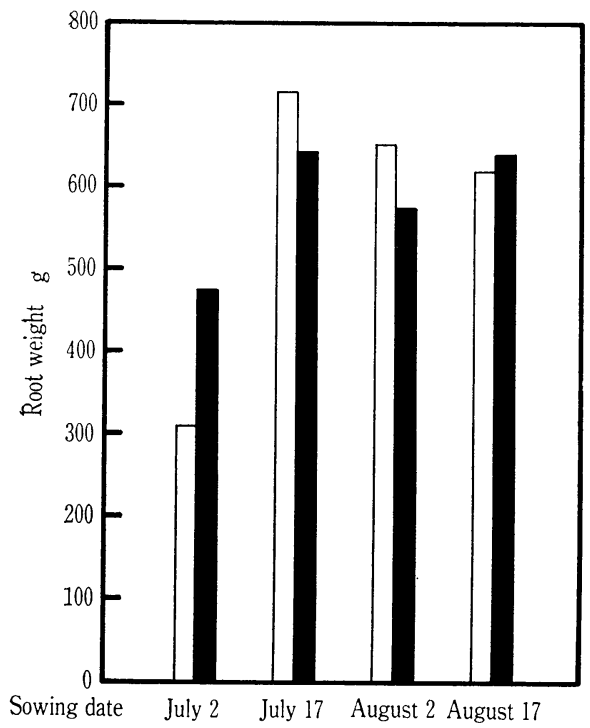

Fig. 6. Effect of soil temperature on the growth of 'Gensuke' roots. $\square$ : control. $\square$ : cooling treatment.

1y, 60 days after sowing (Fig. 5). The occurrence was extremely low in plants sown from the beginning of August. Especially, no hollow root was observed in plants sown on September 1. In 1985, the occurrence of hollow root 60 days after sowing was $20 \%$ in plants sown on July 1 and $40 \%$ in plants sown on July 16 . It was quite low in plants sown during August.

Effect of soil temperature on root growth and the occurrence of hollow root

For plants of the control, a root weight of $310 \mathrm{~g}$ in plants sown on July 2 was the smallest, and a weight of $717 \mathrm{~g}$ in plants sown

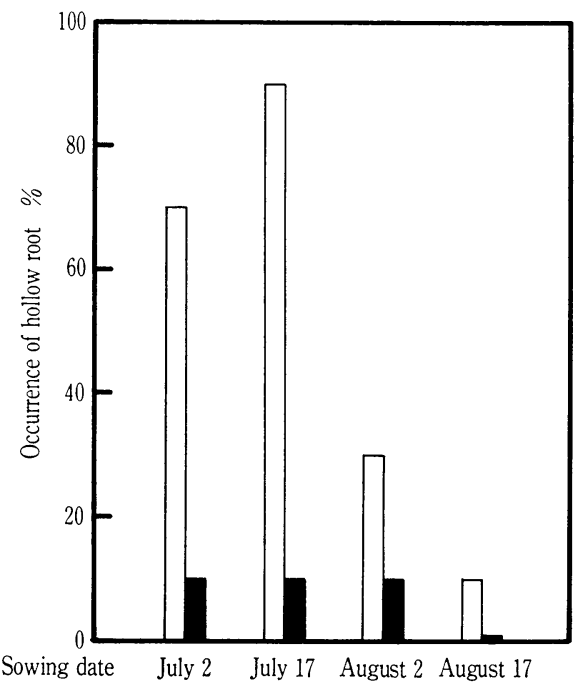

Fig. 7. Effect of soil temperature on the occurrence of hollow root in 'Gensuke'. $\square$ : control. cooling treatment.

on July 17 the greatest(Fig. 6). The weights in plants sown from August 2 on were almost the same. On the other hand, for plants of the cooling treatment, the weight in plants sown on July 2 was $165 \mathrm{~g}$ greater than that of the control, although the weights in plants sown on July 17 and August 2 were nearly $75 \mathrm{~g}$ smaller than those of the control. The weight in plants sown on August 17 was almost the same as that of the control.

The occurrence of hollow root in plants sown on July 2 in the control was $70 \%$, with a greatest occurrence of $90 \%$ in plants sown on July 17(Fig. 7). Thereafter, the occur- 
rence decreased to $30 \%$ and $10 \%$ at later sowing dates. On the contrary, in the cooling treatment, the occurrence in plants sown on July 2, July 17 and August 2 was $10 \%$, and no hollow root was observed in plants sown on August 17.

\section{Discussion}

In this experiment, two types of hollowness were observed in the root of 'Gensuke'. Similar observations in several cultivars of Japanese radishes have been reported $(2,7,9)$. From the results of Tamada and Emura(7), it might be accepted that one of the causes of blackish-brown staining with hollowness is the invasion of pathogenic fungi and/or bacteria. Hollow root began to be recognized 20-30 days after sowing, while root weight increased rapidly from the 30 th day. This is consistent with the results for 'Gensuke' reported by Inabe and Watanabe(3) and Watanabe et al. (11). Toyotomi and Imaizumi(9) stated that hollowness in radish roots originated from the cracks which developed from the intercellular space in parenchymatous tissues or in the vessels. My data indicate that in 'Gensuke' the cracks begin to occur on the very beginning of root growth and develop in to hollowness along with rapid root growth from the 30 th day after sowing.

The occurrence of hollow root at harvest was high in plants sown during July, while lo $r$ in plants sown from the beginning of August on. Similar results have been reported for 'Gensuke'(11) and 'Taibyosobutori' (12). Thus, the occurrence of hollow root is lower with later sowing dates in summersown culture of radish. In the present experiment, air and soil temperatures during the growing period were high for sowings duriıg July, but low for sowings from the beginning of August on. Thus, the occurrence of hollow root is high in plants grown under high air and/or soil temperature(s). On the other hand, root weight was great in plants sown during July, with exception of plants sown on July 2 in 1984, while the weight was small in plants sown from the beginning of August on. It seems that roots with excellent growth show a tendency to high occurrence of hollow root. These results show that one of the causes for high occurrence of hollow root in radish sown during July is high air and/or soil temperature(s) during the growing period.

The occurrence of hollow root under the cooling treatment of soil was quite low compared to that of the control. It has been reported that lowering soil temperature by mulching can reduce hollow root in summersown culture of radishes $(6,11)$. Therefore it is possible to say that the occurrence of hollow root at lower soil temperatures is low even when the air temperature is high during the growing period. With regard to root growth under the cooling treatment, plants sown on July 2 formed larger roots than those sown on July 17 and August 2. In this case, no relationships were recognized between root growth and the occurrence of hollow root.

In conclusion, causes for high occurrence of hollow root of 'Gensuke' sown during July are high air and/or soil temperature(s) during the growing period, and soil temperature plays much the more important role.

\section{Acknowledgment}

The author expresses his thanks to $\mathrm{Mr}$. Hiroto Koike for assistance in conducting the present study, and to Dr. Kenji Shiozawa, Professor of Ishikawa Agricultural College for his valuable suggestions on this study. The author is grateful to Dr. Tadashi Asahira, Professor of Kyoto University for his critical reading of the manuscript.

\section{Literature Cited}

1. Department of Breeding, Vegetable and ORNAMENTAL CROPS RESEARCH Station. 1980. Local varieties of vegetables in Japan. p. 9899. Department of Breeding, Vegetable and Ornamental Crops Research Station. (In Japanese).

2. ICHikaWA, H., T. KaWAi and S. AKITA. 1980. Study on the hollow root in Japanese radishes. I. Some relationships of different varieties to the occurrence of hollow root. Abstr. Japan. Soc. Hort. Sci. Autumn Meet. 1980. 194-195. (In Japanese).

3. INABE, Y. and N. WATANABE. 1971. Investi- 
gations on the growth of a Japanese radish, 'Gensuke'. The file of experimental results on vegetables of Ishikawa. sand dune Agric. Exp. Stn. 1970. 67-70. (In Japanese).

4. KANAZAWA MUNICIPAL CENTRAL WHOLESALE MARKET. 1984. The annual report of Kanazawa municipal central wholesale market. (In Japanese).

5. KaWAI, T., H. IChIKAWA and S. AKITA. 1980. Study on the hollow root in Japanese radishes. II. Effect of sowing date on the occurrence of hollow root. Abstr. Japan. Soc. Hort. Sci. Autumn Meet. 1980. 196-197. (In Japanese).

6. Nishikawa, H., K. Tsutsui and S. Sugimoto. 1972. Factors affecting the occurrence of 'Kūdō-sho', cavity-disease, in 'Gensuke' radish. Bull. Tonami Hort. Branch. Toyama Agric. Exp. Stn. 12:23-35. (In Japanese with English summary).

7. TAmada, A. and M. EmURA. 1981. Effect of sowing date on the occurrence of hollow root in a Japanese radish, 'Taibyosobutori'. The file of experimental results of Uchino Branch. Niigata. Hort. Exp. Stn. 1980. 6365. (In Japanese).

8. TAmada, A. and M. EmURA. 1982. Effect of soil acidity on the occurrence of hollow root in a Japanese radish, 'Taibyosobutori'. The file of experimental results of Uchino Branch. Niigata. Hort. Exp. Stn. 1981. 8081. (In Japanese).

9. Tочотомi, Y. and H. Imaizumi. 1970. Study on the occurrence of hollow root in a different soil textures and the histological observations of the hollow root. Abstr. Japan. Soc. Hort. Sci. Autumn Meet. 1970. 114115. (In Japanese).

10. Tочотомі, Y. 1974. Hollow root in Japanese radish. In Cyclopedia of techniques for cultivating vegetables and upland crops. II. Vegetables. Ed. Agriculture, forestry and fisheries research council. Nogyogijutsukyokai. Tokyo. 276-277. (In Japanese).

11. Watanabe, N., T. Nakazawa., K. OE., K. FujiTA., T. Murata., T. SaWamoto., H. Kita., K. ITASAKA., H. KAKITA and T. TAKAGI. 1976. Effect of sowing date and shade on the occurrence of hollow root in a Japanese radish, 'Gensuke'. The file of experimental results on vegetables of Ishikawa. sand dune Agric. Exp. Stn. 1975. 100-109. (In Japanese).

12. Watanabe, N., Y. Nishikawa., T. NakaZawa., K. OE., T. Odagiri., T. SAWamoto., H. Kita., K. ITASAKA., K. KAKITA and T. IMAI. 1983.

Study on the sowing date and planting density in a Japanse radish, 'Taibyosobutori'. The file of expermental results on vegetables of Ishikawa. sand dune Agric. Exp. Stn. 1982. 73-76. (In Japanese).

13. YoshikAWA, S. and H. ISHIZAKI. 1972. III. Experiments for suppressing the occurrence of hollow root in a Japanese radish, 'Misonoichigo'. The file of experimental results on soil and plant nutrition of Mie. Agric. Tec. Center. 1971. 14-18. (In Japanese). 


\title{
源助ダイコンの空洞症発生における温度の役割 \\ 加 納 恭 卓 \\ 石川県農業短期大学 921 石川県石川郡野々市町
}

\begin{abstract}
摘要
源助ダイコンを高温期には種した場合, 根部の中心部 が縱に空洞となる空洞症の発生原因を明らかにするた め, 1984年と1985年の 7 月, 8 月および 9 月の 3 ケ月に わたり15日間おきには種し, 根部の生育ならびに空洞発 生について調查し,ささらにパイピングした水道水で地温 を低下させたうねに1984年の 7 月と 8 月には種し同様な 調査を行った。

1. 1984年, 1985 年とも最高気温・地温ともに 7 月 31 日から 8 月 15 日の期間で最も高かった. うねの冷却処理 を行った場合, 地温はこの時期の対照区に比べて約 $6^{\circ} \mathrm{C}$

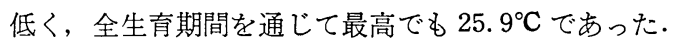

2. は種後60日目の根重は, 1984年では 7 月17日に,

た、空洞症には空洞内部が黒褐色に着色したものと, ったく着色していないものの 2 種類があった。空洞発生 率は，は種後20一30日目ごろから増大しはじめた。1984 年, 1985 年ともは種後60日目の空洞発生率は, 7 月上旬 から中旬には種した場合最も高く, 7 月下旬以降のは種 では低くなった。

3.らねの冷却処理を行った場合，は種後60日目では 対照区に比べ空洞発生率は低くなり，とくに 7 月中のは 種では空洞発生率の低下が著しかった.

これらのことより，源助ダイコンの根部における空洞 の発生には高地温が重要な働きをしているものと考兄ら れる.
\end{abstract} 1985年では 7 月 1 日には種した場合に最も大きくなっ 